Современное распространение и прогноз расширения инвазионного ареала уссурийского полиграфа Polygraphus proximus Blandford, 1894 в Томской области (Западная Сибирь)

\title{
Current distribution and forecasted invasive area expansion of the four-eyed fir bark beetle Polygraphus proximus Blandford, 1894 in Tomskaya Oblast' (Western Siberia)
}

\author{
С.А. Кривеч*, И.А. Керчев*, Э.М. Бисирова*, **, Н.М. Аебков* \\ S.A. Krivets*, I.A. Kerchev*, E.M. Bisirova*,**, N.M. Deblov*
}

\footnotetext{
* Институт мониторинга климатических и экологических систем СО РАН, пр. Академический 10/3, Томск 634055 Россия. E-mail: krivec_sa@mail.ru, ikea86@mail.ru, bissirovaem@mail.ru, nikitadebkov@yandex.ru.

* Institute of Monitoring of Climatic and Ecological Systems, Russian Academy of Sciences, Siberian Branch, Akademichesky Ave. 10/3, Tomsk 634055 Russia.

** Томский филиал Всероссийского центра карантина растений, пр. Фрунзе, 109А, Томск 634069 Россия.

** Tomsk Branch of the All-Russian Plant Quarantine Center, Frunze Ave. 109A, Tomsk 634069 Russia.
}

Ключевые слова: Polygraphus proximus, инвазионный ареал, Томская область, Западная Сибирь.

Key words: Polygraphus proximus, invasive area, Tomskaya Oblast', Western Siberia.

Резюме. Изучено распространение инвазионного короеда - уссурийского полиграфа Polygraphus proximus Blandford, 1894 на территории Томской области. В peзультате исследований, проведённых в 2008-2017 гг., инвайдер обнаружен в 13 районах области, где он вызывает усыхание пихты сибирской Abies sibirica Ledeb., 1833. Общая площадь ареала полиграфа составляет 111360 км², протяжённость - 256 км с юга на север и 435 км с запада на восток. Прогнозируется дальнейшее распространение уссурийского полиграфа на север и запад, обусловленное ослаблением пихтовых и смешанных с участием пихты древостоев, в том числе в результате вспышки массового размножения сибирского шелкопряда Dendrolimus sibiricus Tschetv., 1908, начавшейся в 2015 г.

Abstract. A species previously known as a Far-Eastern endemic, the four-eyed fir bark beetle Polygraphus proximus Blandford, 1894 (Coleoptera, Curculionidae: Scolytinae), introduced into South Siberia, has become one of the most aggressive pests in terms of the recent large-scale degradation of Siberian fir forests. The Tomskaya Oblast is the first region where it was authentically recorded in 2008 and a special investigation of its invasion began. The aim of this study is to summarize the data on the distribution of $P$. proximus in the Tomskaya Oblast over a 10 -year period of extensive field research. Locations of the $P$. proximus were identified on the basis of characteristic signs of damage to fir trees by this insect and mandatory verification of taxonomic accessory of collected beetles.

Currently, the fir bark beetle has been detected in 13 districts of the Tomskaya Oblast, where it causes the death of the Siberian fir Abies sibirica Ledeb., 1833. The most widespread and highest population densities of $P$. proximus are found in the south-eastern districts, located on the right-hand bank of the Ob' River in the area of the initial stage of invasion, where Siberian fir forms degradated stands. Total area of the bark beetle distribution is more than $100,000 \mathrm{~km}^{2}$
( $256 \mathrm{~km}$ from $\mathrm{S}$ to $\mathrm{N} \& 435 \mathrm{~km}$ from $\mathrm{W}$ to $\mathrm{E}$ ). The northern limit of the current boundary of the alien species expansion coincides with the northern boundary of the southern taiga forest area. Further spread to the north and west of the region is forecast due to degradation of fir and mixed stands with fir, also caused by the outbreak of Siberian moth Dendrolimus sibiricus Tschetv., 1908 which began in 2015.

\section{Введение}

Уссурийский (пихтовый) полиграф Polygraphus proximus Blandford, 1894 (Coleoptera, Curculionidae: Scolytinae), завезённый на территорию Южной Сибири дальневосточный эндемичный вид, является в настоящее время наиболее агрессивным из всех известных видов короедов в сибирских пихтовых лесах и одним из основных в комплексе факторов их усыхания [Baranchikov et al., 2010; Baranchikov, Krivets, 2010; Krivets et al., 2013]. Как инвайдер, уссурийский полиграф относится к так называемым «местным экзотикам» (domestic exotics), преодолевающим биогеографические рубежи внутри стран и континентов [Baranchikov et al., 2011a]. Первичный ареал $P$. proximus приурочен к юго-восточной части Северной Азии (юг российского Дальнего Востока, Корея, Япония, северо-восточный Китай), где он развивается преимущественно на дальневосточных видах рода Abies Mill., реже на других видах хвойных [Kurentsov, 1950; Stark, 1952; Krivolutskaya, 1958; Nobuchi, 1979], и не имеет существенного значения как вредитель в лесном хозяйстве.

Проникновение уссурийского полиграфа в таёжные экосистемы Сибири и формирование здесь в последние десятилетия многочисленных очагов его 
массового размножения в насаждениях пихты сибирской Abies sibirica Ledeb. в равнинных и горных районах — уникальный, единственный известный в настоящее время случай крупномасштабной инвазии в этот регион насекомого-дендрофага дальневосточного происхождения, имеющей значительные экономические и экологические последствия [Baranchikov, 2012; Krivets et al., 2015a].

Как особо опасный инвазионный вид (т.е. натурализовавшийся чужеродный биологический вид, нанёсший существенный ущерб аборигенным видам и экосистемам), P. proximus является кандидатом для включения в список приоритетных видовмишеней для исследования и контроля на территории России [Dgebuadze, 2014]. Решением Совета Евразийской экономической комиссии от 30 ноября 2016 г. № 158 уссурийский полиграф внесён в Единый перечень карантинных объектов Евразийского экономического союза, что ужесточает контроль его распространения с целью снижения фитосанитарного риска.

Томская область - первый регион Сибири, где в 2008 г. было достоверно установлено присутствие в лесах уссурийского полиграфа (идентифицирован ведущим российским систематиком по короедам М.Ю. Мандельштамом). С 2010 г., когда сотрудниками Томского филиала ФБУ «Рослесозащита» были выявлены очаги его массового размножения в южной части области, нами проводятся специальные исследования распространения, биологии, экологии инвайдера и его влияния на состояние пихтовых лесов. Сведения о находках $P$. proximus на территории Томской области периодически обновлялись [Baranchikov et al., 2011b; Krivets et al., 2011; Kerchev, Krivets, 2012; Krivets et al., 2015b, Four eyed fir bark beetle..., 2015]. Цель настоящей работы - обобщение данных, накопленных за десятилетний период исследований, для выявления общей картины современного вторичного ареала $P$. proximus в пределах Томской области, что важно не только для понимания особенностей инвазионного процесса и прогнозирования дальнейшего распространения инвайдера, но и для разработки системы мониторинга и защиты лесов от опасного вредителя.

\section{Материалы и методы}

Сведения о распространении $P$. proximus на территории Томской области получены авторами в ходе обширных экспедиционных исследований в 20082017 гг. в 10 административных районах области: Асиновском, Томском, Бакчарском, Верхнекетском, Колпашевском, Кривошеинском, Первомайском, Тегульдетском, Чаинском и Шегарском.

Дополнительно использованы данные о находках инвайдера (в том числе в в Кожевниковском, Зырянском и Молчановском районах), любезно предоставленные сотрудниками Томского филиала ФБУ «Рослесозащита», Отдела охраны и защиты лесного фонда Департамента лесного хозяйства Томской области, лесничеств ОГКУ «Томсклес», лесозаготовительных и природоохранных организаций.

Местонахождения уссурийского полиграфа выявлялись на основе комплекса характерных признаков присутствия данного вида в насаждении [Four eyed fir bark beetle..., 2015]: наличие свежего сухостоя - погибших деревьев с мёртвой хвоей красного цвета; потёки смолы на стволах пихты - следы атак полиграфа на живые деревья; мелкие входные и вылетные отверстия жуков на коре погибших деревьев, типичные маточные ходы под корой (как правило, двухколенные, расположенные в разных направлениях), куколочные камеры, погружённые в заболонь; некрозы флоэмы от переносимых полиграфом фитопатогенных офиостомовых грибов на отмирающих деревьях.

Основным доказательством обитания инвайдера в насаждениях являлось обнаружение под корой пихт жуков с диагностическими признаками, отличающими P. proximus от местных видов, изредка встречающихся на пихте сибирской - полиграфа пушистого P. poligraphus (Linnaeus, 1758) и полиграфа малого елового P. subopacus Thomson, 1871: усик с 6-члениковым жгутиком и удлинённой и закруглённой на конце булавой, а также более крупные размеры тела [Stark, 1952].

Географические координаты мест обнаружения уссурийского полиграфа определялись с использованием GPS-навигатора Garmin (США). Характеристики насаждений устанавливались путём перечислительноизмерительной таксации при закладке пробных площадей в местах нахождения инвайдера по общепринятым методам лесоводственных исследований [Chmyr et al., 2001]. Типы леса на пробных площадях, в том числе производные варианты растительных сообществ, сформировавшиеся в результате трансформации исходного напочвенного покрова в повреждённых полиграфом насаждениях, определены научным сотрудником ИМКЭС СО РАН к.б.н. Н.А. Черновой.

В формуле древостоя: П- пихта сибирская Abies sibirica Ledeb. (П - I поколение, П - II поколение); К - сосна сибирская кедровая Pinus sibirica Du Tour; E - ель сибирская Picea obovata Ledeb., C - сосна обыкновенная Pinus sylvestris L., Б береза Betula spp., Oc - осина Populus tremula L. Цифры перед буквами обозначают долю породы в древостое; ед. - встречается единично, + - присутствует в примеси.

\section{Результаты}

Ниже приведены данные о распространении уссурийского полиграфа в районах Томской области. Районы в тексте расположены в последовательности с юга на север и с запада на восток. Указаны ближайшие населённые пункты, годы находок, характеристики насаждений, координаты местонахождений.

Кожевниковский р-н., 2011-2012 гг.:

c. Старая Ювала, на пихтах, растущих как примесь в припоселковом кедровнике (географические координаты местонахождения 56¹7'59" с.ш., 
$083^{\circ} 26^{\prime} 05^{\prime \prime}$ в.д.). Информация предоставлена участковым лесничим Ювалинского участкового лесничества Кожевниковского лесничества А.Ю. Моисеевым.

Бакчарский р-н., 2017 г.:

д. Плотниково, пихтарник осочково-мелкотравный, состав древостоя 8П1Е1Б+К1 (100 лет), 56 54 '40" с.ш., $083^{\circ} 03^{\prime} 13^{\prime \prime}$ в.д.;

д. Больщая Галка, пихтарник разнотравный, 7П1Е2Б, ед. Ос (95 лет), 5654'45" с.ш., 08153'37" в.д.; пихтарник закустаренный осочково-мелкотравный, 6П2Е1Б1Ос (80 лет), 56 55'51" с.ш. , 081 $599^{\prime} 09^{\prime \prime}$ в.д.;

c. Парбиг, пихтарник разнотравный, 9П1Б+К $(70$ лет), 57¹6'35" с.ш., 081³0'18" в.д.

Шегарский р-н., 2014-2017 гг.: д. Бушуево, пихтарник папоротниково-мелкотравный, 6П1К1Е2Б+Ос (70 лет), 5654'13" с.ш., 084²16'33" в.д. (Каргалинское урочище). По сообщению главного лесничего Шегарского лесничества Е.В. Брусенцева, в этом же урочище отмечен в разнотравных пихтарниках (75140 лет), 5654'32"-5654'59"с.ш., 084¹0'55"$084^{\circ} 11^{\prime} 08^{\prime \prime}$ в.д.;

c. Монастырка, пихтарник разнотравный, 4ПЗЕ1К1Б1Ос (95 лет), 5656'32" с.ш., 08333'50" в.д. (Информация Е.В. Брусенцева).

г. Томск, 2013 г.: Университетская роща, посадки пихты сибирской (56²8'12" с.ш., 08456'58" в.д.), Сибирский ботанический сад, Заповедный парк, посадки пихты сибирской (56²7'59" с.ш., 08456'51" в.д.) Лагерный сад, посадки пихты сибирской (56²7'14" с.ш., 08456'57" в.д.), Академгородок, посадки пихты сибирской (56²8'28" с.ш., 08502'56" в.д.).

Томский р-н., 2008-2017 гг.:

c. Батурино, особо охраняемая природная территория (далее ООПТ) «Ларинский ландшафтный заказник», ельник разнотравный, $5 \mathrm{E} 3 \Pi_{1} 1 \Pi_{2} 1 \mathrm{~K}+\mathrm{C}\left(\Pi_{1}-\right.$ 95 лет, П — 55 лет), 56 $12^{\prime} 31^{\prime \prime}$ с.ш., 08502'19" в.д.; кедровник разнотравный, 3К6П1Е (60 лет), 56 $122^{\prime} 36^{\prime \prime}$ с.ш., $085^{\circ} 02^{\prime} 05^{\prime \prime}$ в.д.; погибшие от полиграфа насаждения с исходным породным составом $6 \Pi_{1} 1 \Pi_{2} 2 \mathrm{~K} 1 \mathrm{E}+\mathrm{Oc}\left(\Pi_{1}-100\right.$ лет, $\Pi_{2}-50$ лет $)$ $56^{\circ} 12^{\prime} 4^{\prime} 1^{\prime \prime}$ с.ш., $085^{\circ} 01^{\prime} 49^{\prime \prime}$ в.Д., и 8 П1К1Е + С (95 лет), $56^{\circ} 12^{\prime} 44^{\prime \prime}$ с.ш., $085^{\circ} 02^{\prime} 20^{\prime \prime}$ в.Д.;

станция "26 км» ветки «Томск-Тайга» ЗападноСибирской железной дороги, осинник разнотравный, 9Ос1Б+П, пихта - 65 лет, 56 $6^{\circ} 12 ' 22^{\prime \prime}$ с.ш., 085²6'28" в.д.;

n. Басандайка, пихтарник вейниково-разнотравный, 10П+Е ед. К, Ос, Б (60 лет), 56¹7'32" с.ш., $085^{\circ} 28^{\prime} 25^{\prime \prime}$ в.д.;

станция "41 км» ветки «Томск-Тайга» Западно-Сибирской железной дороги, ООПТ — памятник природы «Таловские чаши», неоднородный по составу участок леса, с участием пихты от 2 (80с2П+Б) до 8 единиц (8П1Е1Ос), возрастом 75-85 лет, $56^{\circ} 17^{\prime} 50^{\prime \prime}$ с.ш., $085^{\circ} 25^{\prime} 16^{\prime \prime}$ в.Д.;

д. Белоусово, ООПТ - памятник природы «Белоусовский припоселковый кедровник», $10 \mathrm{~K}+\Pi$, 56 18 '39" с.ш., $085^{\circ} 10^{\prime} 28^{\prime \prime}$ в.Д.;

д. Аксеново, ООПТ - памятник природы «Аксеновский припоселковый кедровник», в кедровых на- саждениях (5-6К) с участием пихты 1-2 единицы возрастом 75-85 лет и примесью ели, сосны и берёзы, 56 $18^{\prime} 46^{\prime \prime}$ с.ш., $085^{\circ} 08^{\prime} 21^{\prime \prime}$ в.д.; в сосновых насаждениях с составом 6С2К1Е1П, возрастом пихты 85-110 лет, $56^{\circ} 18^{\prime} 41^{\prime \prime}$ с.ш., $085^{\circ} 08^{\prime} 20^{\prime \prime}$ в.Д.;

c. Петухово, ООПТ - памятник природы «Петуховский припоселковый кедровник», кедровник разнотравный, 9К1П+Е, С, 56¹9'10" с.ш., 085¹5'49" в.д.; кедровник разнотравный, 7К2П1Е+С, пихта 95 лет, 56 19 '43" с.ш., $085^{\circ} 16^{\prime} 53^{\prime \prime}$ в.д.; кедровник разнотравный, 7КЗП+Е, С, пихта 110 лет, 56 19 '50" с.ш., 084 $16^{\prime} 00^{\prime \prime}$ в.д.; ельник разнотравный, 6Е2П1К1С, пихта 95 лет, 56 19 '41" с.ш., $085^{\circ} 14^{\prime} 55^{\prime \prime}$ в.Д.;

д. Большое Протопопово, ООПТ - памятник природы «Протопоповский припоселковый кедровник», 10К+С, Е, П; 10К+П, пихта возрастом 40-60 лет, $56^{\circ} 24^{\prime} 52^{\prime \prime}$ с.ш., $085^{\circ} 09^{\prime} 43^{\prime \prime}$ в.д.;

n. Заварзино, ООПТ - памятник природы «Заварзинская лесная дача», кедровник разнотравнозеленомошный, 5К3П2Е+С (пихта 110 лет), $56^{\circ} 27^{\prime} 53^{\prime \prime}$ с.ш., $085^{\circ} 06^{\prime} 46^{\prime \prime}$ в.д.; кедровник мозаичный, мелкотравный и закустаренный крапивный, 4К5П1Е ед. Б (70 лет), 56²7'54" с.ш., 08506'55" в.д.; пихтарник кустарниковый разнотравно-зеленомошный, 5ПЗЕ2К (70 лет), 56²7'55" с.ш., $085^{\circ} 06^{\prime} 46^{\prime \prime}$ в.д.;

c. Зоркальцево, ООПТ - памятник природы «Зоркальцевский припоселковый кедровник», кедровник разнотравный, 9К1П, пихта 85 лет; 56³2'06" с.ш., 08444'01" в.д.;

д. Кудринский участок, ООПТ - памятник природы «Нижне-Сеченовский припоселковый кедровник», кедровник разнотравный, $10 \mathrm{~K}+\mathrm{E}, \Pi$; 56³0'27" с.ш., $084^{\circ} 38^{\prime} 38^{\prime \prime}$ в.д.;

д. Берёзовая речка, ООПТ «Томский зоологический заказник», пихтарник осочково-зелёномошный, 9П1Е+К, Ос, ед. Б(95 лет), 5605'01" с.ш., 084²12'43" в.д. ООПТ «Калтайский зоологический заказник», смешанный крупнопапоротниковый лес, 2П2Е6Б, ед. К (80 лет), 56¹0'39" с.ш., 084²5'38" в.д.; пихтарник осочково-мелкотравный, 6П1КЗБ, ед. Е, Ос (70 лет); 56¹1'12" с.ш., 084²6'18"в.д.; пихтарник крупнопапоротниково-мелкотравный, 5П2ЕЗБ, ед. К (90 лет), 56¹1'56"с.ш., 084²6'39"в.д.;

c. Итатка, ельник разнотравный, 4ЕЗПЗБ+К (пихта — 85 лет), 56²9'15" с.ш., 085³7'07" в.д.; пихтарник мелкотравный, 6ПЗЕ1К+Б (110 лет), 56²9'20" с.ш., 085³7'34" в.д. ;

c. Малиновка, пихтарник разнотравный, 9П1Е+Б, ед. К, С (75 лет), 56²'10" с.ш., 085²0'46" в.д.;

д. Нагорный Иитан, на пихтах в деревне и в окрестностях, 56²4'54" с.ш., 084³3'04" в.д.

По данным Томского филиала ФБУ «Рослесозащита», очаги массового размножения уссурийского полиграфа в Томском районе (в пределах Межениновского участкового лесничества Томского лесничества и Калтайского участкового лесничества Тимирязевского лесничества) были зарегистрированы на территории с координатами 56 $10^{\prime} 55^{\prime \prime}-$ $56^{\circ} 20^{\prime} 28^{\prime \prime}$ с.ш., $084^{\circ} 24^{\prime} 51^{\prime \prime}-085^{\circ} 35^{\prime} 02^{\prime \prime}$ в.д. в лесах с уча- 
стием пихты в составе древостоев 4-10 единиц, возрастом 65-110 лет.

Зырянский р-н., 2012-2017 гг.:

c. Тукай, местонахождения уссурийского полиграфа в пределах Нижне-Четского урочища Окунеевского участкового лесничества Зырянского лесничества, с географическими координатами

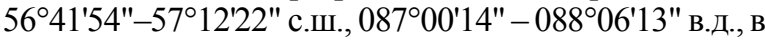
эксплуатационных лесах с участием пихты в составе древостоев 2-7 единиц, возрастом 95-150 лет (информация начальника лесохозяйственного производства ООО «Латат» А.Д. Касьянова и ответственного за сертификацию в ООО «Сибирьлес» Ю.А. Наумова, Центра защиты леса и Департамента лесного хозяйства Томской области). Также на территории ООПТ «Тонгульский зоологический заказник», 5653'17" с.ш., 08744'31" в.д. (Сообщение егеря Ф.В. Куманичина);

c. Чердаты, действующие очаги массового размножения уссурийского полиграфа в эксплуатационных темнохвойных лесах Кийского урочища Чердатского участкового лесничества Зырянского лесничества, с участием пихты в составе насаждений 3-4 единицы, возрастом 90-115 лет, географические координаты $57^{\circ} 08^{\prime} 21^{\prime \prime}-57^{\circ} 10^{\prime} 43^{\prime \prime}$ с.ш., $088^{\circ} 08^{\prime} 54^{\prime \prime}-088^{\circ} 12^{\prime} 41^{\prime \prime}$ в.д. (По информации Департамента лесного хозяйства и Центра защиты леса Томской области).

Тегульдетский р-н., 2011-2016 гг.:

n. Четь-Конторка, ООПТ «Южнотаёжный ботанический заказник», пихтарник мелкотравно-осочковый, 6ПЗБ1К+Е, ед. Ос (70 лет), 5702'22" с.ш., $088^{\circ} 02^{\prime} 48^{\prime \prime}$ в.д.; погибшие от полиграфа насаждения с исходным составом 7П2Б1Е+К (115 лет) и 10П+К, Б

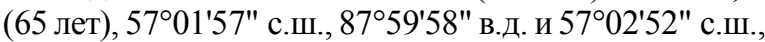
$088^{\circ} 07^{\prime} 01^{\prime \prime}$ в.д., соответственно. Присутствие полиграфа и очаги его массового размножения в этой части района (Четское участковое лесничество Тегульдетского лесничества) отмечены также в разнотравных и мшистых эксплуатационных лесах с участием пихты в составе древостоев 3-7 единиц, возрастом 50115 лет, на территории с координатами 56 $55^{\prime} 44^{\prime \prime}-$ 5703'56"с.ш., 087³8'41"-08808'18" в.д. (Информация Центра защиты леса и Департамента лесного хозяйства Томской области);

n. Чёрный Яр, пихтарники вейниково-осочковые, составом 6П2Е 2Б+К (90 лет), 57008'46" с.ш., $087^{\circ} 42^{\prime} 42^{\prime \prime}$ в.д. и 4П1Е5Б+К, Ос (110 лет), 5708'48" с.ш., $087^{\circ} 42^{\prime} 46^{\prime \prime}$ в.д. Очаги массового размножения полиграфа в этой части района (Черноярское участковое лесничество Тегульдетского лесничества) отмечены в разнотравных и мшистых эксплуатационных лесах с участием пихты в составе древостоев 2-7 единиц, возрастом 60-150 лет, на территории с координата-

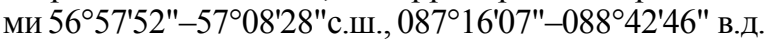
(Информация Центра защиты леса и Департамента лесного хозяйства Томской области);

n. Берегаево, пихтарник разнотравный, 3П2Е1К3Б1Ос, 80 лет, 57²1'56" с.ш., 087³2'22" в.д.; c. Тегульдет, пихтарник мелкотравно-осочковый, 5П3Ос1Е1Б+К(110 лет), 10П+Е, К(80 лет), 57¹3'37" с.Ш., 08811'36" в.д.; пихтарник осочковый, 5П1Е1КЗБ+Ос (125 лет), 57¹4'05" с.ш., 088¹1'53" в.д. Очаги массового размножения полиграфа в этой части района (Тегульдетское участковое лесничество Тегульдетского лесничества) отмечены также в эксплуатационных лесах с участием пихты в составе древостоев 3-6 единиц, возрастом 60-130 лет, на территории с координатами 56 $13^{\prime} 10^{\prime \prime}-57^{\circ} 43^{\prime} 37^{\prime \prime}$ с.ш., 087²7'53"-08820'11" в.д. (Информация Центра защиты леса и Департамента лесного хозяйства Томской области);

n. Белый Яр, пихтарник разнотравный, 4П2Е1КЗБ (85 лет), 57²9'43" с.ш., 08845'35" в.д. (Куяновское урочище Средне-Чулымского участкового лесничества Тегульдетского лесничества).

Чаинский р-н. 2017 г.:

c. Лось-Гора, пихтарник осочковый, 4ПЗЕ1К2Ос+Б (100 лет), 57³0'50" с.Ш., 082¹8'35" в.Д.;

c. Стрельниково, ООПТ «Поскоевский зоологический заказник», пихтарник осочково-мелкотравный, 6П1К1Е2Б, ед. Ос (80 лет), 57²7'17" с.ш., $082^{\circ} 12^{\prime} 34^{\prime \prime}$ в.д.

Кривошеинский р-н., 2012-2017 гг.:

c. Кривошеино, смешанное насаждение мелкотравного типа леса, 2П2С1К1Е3Ос1Б (пихта - 90 лет), 57¹9'38" с.ш., 08354'59" в.д.; сельский парк с пихтой

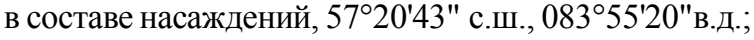

c. Жуково, пихтарник разнотравный, 8П2Е+К, ед. С (90 лет), 57²4'27" с.ш., 08355'16" в.д.; пихтарник мелкотравный, 8П1Б1Ос+К, Е (90 лет), 57²4'31" с.ш., $083^{\circ} 55^{\prime} 22^{\prime \prime}$ в.д.

Молчановский р-н. 2012 г.:

c. Молчаново, ООПТ «Верхне-Соровский зоологический заказник», пихтарники зеленомошно-ягодные, с участием пихты 3-5 единиц, 100-160 лет, 57²9'34" с.ш., $084^{\circ} 16{ }^{\prime} 27^{\prime \prime}$ в.д. (По данным Отдела заказников Областного комитета охраны природы и природопользования Томской области).

Асиновский р-н., 2016 г.:

с. Больще-Дорохово, пихтарник кустарниковый разнотравный, 4П2Е2Б2Ос+К (80 лет), 56 533'09" с.ш., $086^{\circ} 14 ' 28$ " в.д.; пихтарники кустарниковые крапивно-крупнопапоротниковые, составом 4П2Е2К1Б1Ос (70 лет) 56 52 '55" с.ш., $086^{\circ} 14^{\prime} 34^{\prime \prime}$ в.д. и 6П2Е1К1Б+Ос (130 лет), 565' $40 "$ с.ш., $086^{\circ} 19 ' 23 "$ в.д.

Первомайский р-н., 2011-2017 гг.:

д. Малиновка, пихтарники разнотравные, составом 9П1Б+К, Е (55 лет), 5700'40" с.ш., 086 50'15" в.д. и 4П4Е1К1Б+Ос (85 лет), 5700'49" с.ш., 086 $50^{\prime} 02^{\prime \prime}$ в.д. (Куяновское участковое лесничество Первомайского лесничества);

c. Новомариинка, пихтарник разнотравный, 3П2Е1К 4Ос+Б (85 лет), 5709'28" с.ш., 086³2'01" в.д.; пихтарник осочково-разнотравный, 5П1Е3Ос1Б (80 лет), 5709'54" с.ш., 086³2'16" в.д. (Первомайское участковое лесничество Первомайского лесничества). По данным Центра защиты леса Томской области, уссурийский полиграф отмечался в Первомайском 
участковом лесничестве на территории с координатами $57^{\circ} 00^{\prime} 40^{\prime \prime}-57^{\circ} 09^{\prime} 54^{\prime \prime}$ с.ш., 086³2'01"$086^{\circ} 50^{\prime} 15^{\prime \prime}$ в.д.;

n. Орехово, кедровник папоротниково-разнотравный, 5К4П1Б+Е, ед. К (95 лет), 57²2'27" с.ш., 08701'47" в.д. (Ореховское участковое лесничество Первомайского лесничества);

п. Улу-Юл, 57² $42^{\prime} 47^{\prime \prime}$ с.ш., 08546'57" в.д., УлуЮльское лесничество (по данным Центра защиты леса Томской области).

Верхнекетский р-н., 2013 г.:

д. Тайное, кедровник мелкотравно-зеленомошный, 5КЗП2Е, ед. Б, пихта 135 лет, 58²2'46" с.ш.,

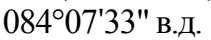

Колпашевский р-н., 2017 г.:

2. Колпашево, пихтарник разнотравный, 6П2К1Е1С+Б, ед. Ос (130 лет), 58²0'26" с.ш., 082 56'28" в.д.; кедровник вейниково-разнотравный, 3К5П1Е1C+Ос, ед. Б (120 лет), 58²0'02" с.ш., $083^{\circ} 00^{\prime} 03^{\prime \prime}$ в.д.; пихтарник мелкотравный, 4П2К1Е3Ос, ед. Б (90 лет), 58²1'41" с.ш., 08300'35" в.д.

В целом выявленный ареал уссурийского полиграфа в Томской области в настоящее время охватывает территорию с географическими координатами $56^{\circ} 04^{\prime}-58^{\circ} 23^{\prime}$ с.ш. и $81^{\circ} 29^{\prime}-88^{\circ} 45^{\prime}$ в.д., протяжённостью 256 км с юга на север и 435 км с запада на восток, общей площадью 111360 км².

\section{Обсуждение и заключение}

В результате систематического изучения инвазии уссурийского полиграфа сведения о его географическом распространении в Томской области постоянно обновляются. В первые годы исследований P. proximus был найден лишь в Томском районе. В 2008-2009 гг. жуки были пойманы в Протопоповском и Белоусовском припоселковых кедровниках

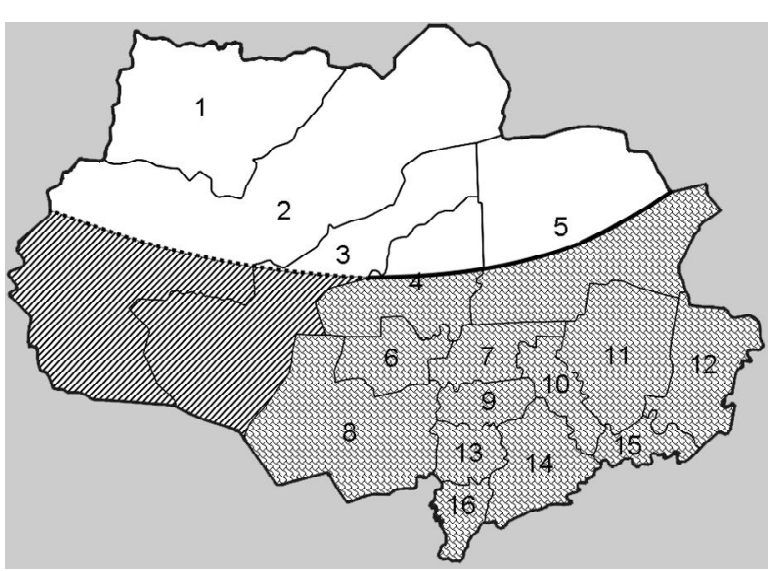

Томского лесничества (5 и 20 км от г. Томска) в феромонные ловушки при их испытаниях с целью мониторинга численности популяций шестизубчатого короеда Ips sexdentatus (Boerner, 1767), главного стволового вредителя сосны сибирской кедровой Pinus sibirica. Позднее инвайдер был найден в этих насаждениях на присутствующих в примеси деревьях пихты сибирской. В 2010 г. появление нового вредителя в лесах Томской области было подтверждено при обследовании темнохвойных древостоев с сильным смолотечением и усыханием пихты в Калтайском участковом лесничестве Тимирязевского лесничества (окр. д. Берёзовая речка, около 50 км от г. Томск).

К 2014 г. P. proximus был обнаружен уже в 9 районах, вплоть до границы с подзоной средней тайги Западно-Сибирской равнины. В последние годы наблюдается расселение инвайдера в леса центральных (Кривошеинского, Чаинского, Молчановского) и южной части северных (Верхнекетского, Колпашевского) районов. К концу 2017 г. выявленный ареал инвайдера охватил территорию 13 из 16 районов Томской области (рис.1).

Уссурийский полиграф встречается в насаждениях различных типов леса, разного породного состава, с долей пихты в составе древостоев от 1 до 10 единиц и даже с незначительным её участием, со средним возрастом от 50 до 160 лет. Наиболее широкого распространения и численности P. proximus достиг в Томском, Зырянском, Первомайском и Тегульдетском районах. В них выявлены очаги массового размножения $P$. proximus и погибшие от него древостои в эксплуатационных лесах и лесах разных категорий защитности, в том числе на особо охраняемых природных территориях - в Ларинском ландшафтном, Южнотаёжном ботаническом, Калтайском зоологическом заказниках, памятниках природы

Рис. 1. Карта распространения уссурийского полиграфа в Томской области (по Аанным на 2017 г.). ААминистративные районы: 1 - Александровский, 2 - Каргасокский, 3 - Парабельский, 4 - Колпашевский, 5 - Верхнекетский, 6 - Чаинский, 7 - Молчановский, 8 - Бакчарский, 9 - Кривошеинский, 10 - Асиновский, $11-$ Первомайский, $12-$ Тегульдетский, 13 - Шегарский, 14 - Томский, 15 - Зырянский, 16 - Кожевниковский.

Fig. 1. Distribution map of P. proximus in Tomskaya Oblast' (according to data for 2017). Administrative districts: 1 Aleksandrovkii, 2 - Kargasokskii, 3 - Parabel'skii, 4 - Kolpashevskii, 5 - Verkhneketskii, 6 - Chainskii, 7 - Molchanovskii, 8 - Bakcharskii, 9 - Krivosheinskii, 10 - Asinovskii, 11 - Pervomaiskii, 12 - Tegul'detskii, 13 - Shegarskii, 14 - Tomskii, 15 - Zyryanskii, 16 - Kozhevnikovskii. 
«Заварзинская лесная дача» и «Таловские чаши». Уссурийский полиграф вызывает деградацию пихтовых крупнотравных лесов вдоль ветки «ТомскТайга» Западно-Сибирской железной дороги, относящихся к редким и нуждающимся в охране растительным сообществам Сибири, усыхание пихты в припоселковых кедровниках-памятниках природы Томской области и искусственных насаждениях населённых пунктов.

Принимая во внимание широкое современное распространение уссурийского полиграфа, очевидно, что сравнительно недавнее «открытие» этого вида в Томской области является запоздалым свидетельством скрыто протекающей на территории Сибири в течение последних десятилетий инвазии $P$. proximus в новые местообитания, которая в последние годы приобрела характер взрывной экспансии. Дендрохронологические исследования позволили датировать вероятный срок проникновения $P$. proximus в леса южной части Томской области серединой 1990-х гг. [Demidko, 2014]. В пользу этого заключения может свидетельствовать также факт нахождения в Тегульдетском лесничестве во время наших исследований в 2016 г. валежного дерева пихты с высокой степенью разложения, погибшего приблизительно 20 лет назад, с характерными следами деятельности уссурийского полиграфа (углублённые в заболонь куколочные камеры).

Основным вектором инвазии уссурийского полиграфа в Томскую область, по-видимому, являлось саморасселение из освоенных ранее чужеродным короедом лесов сопредельных районов Кемеровской области вдоль Транссибирской железнодорожной магистрали - основного транспортного коридора распространения P.proximus. Это подтверждается генетическим сходством томских и кемеровских инвазийных популяций полиграфа [Kononov et al., 2016]. По территории Томской области $P$. proximus также расселяется самостоятельно, чему способствует состояние кормовой базы.

Томская область находится в юго-восточной части Западно-Сибирской равнины. Здесь на водораздельных территориях располагаются основные массивы равнинных западносибирских пихтовых лесов. Как отмечал В.Б. Сочава [Sochava, 1980], участие пихты в темнохвойных лесах (коренных елово-пихтовых, пихтово-еловых и пихтово-елово-кедровых) является характерной чертой зональности растительности Западной Сибири.

Пихтовые леса в Томской области занимают 621 тыс. га, что составляет 2,2\% покрытой лесом площади и 6,4 \% площади хвойных лесов, согласно данным Государственного лесного реестра 2014 г. Пихта сибирская произрастает по всей области, но доминирует в её юго-восточной части, характеризующейся меньшей заболоченностью. Здесь она занимает в разных районах от 6,2 до 10,5 \% покрытой лесом площади и от 22,7 до 46,7 \% площади хвойных лесов (табл. 1) и играет существенную роль в общем объёме лесозаготовок. По мере продвижения на се-

Таблица 1. Пиощадь, занятая пихтой сибирской в Томской области (по данным Государственного месного реестра, 2014)

Table 1. The area occupied by Siberian fir in Tomskay Oblast' (according to the State Forest Register, 2014)

\begin{tabular}{|c|c|c|c|c|}
\hline Административный район & Лесничество & $\begin{array}{c}\text { Общая площадь, } \\
\text { покрытая лесом, га }\end{array}$ & $\begin{array}{c}\text { Площадь } \\
\text { хвойных лесов, } \\
\text { га }\end{array}$ & $\begin{array}{c}\text { Площадь, занятая пихтой, га / } \\
\% \text { от общей площади, покрытой } \\
\text { лесом / \% от площади хвойных } \\
\text { лесов }\end{array}$ \\
\hline Александровский & Александровское & 2592674 & 1003799 & $2099 / 0,1 / 0,2$ \\
\hline Асиновский & Асиновское & 447733 & 179918 & $11407 / 2,6 / 6,3$ \\
\hline Бакчарский & Бакчарское & 2385577 & 723902 & 75569 / 3,2 / 10,4 \\
\hline Верхнекетский & Верхнекетское & 4305201 & 1832791 & $17740 / 0,4 / 1,0$ \\
\hline Зырянский & Зырянское & 258315 & 58068 & $27151 / 10,5 / 46,7$ \\
\hline Каргасокский & $\begin{array}{l}\text { Каргасокское } \\
\text { Васюганское }\end{array}$ & $\begin{array}{l}5422797 \\
2983376 \\
\end{array}$ & $\begin{array}{c}2223929 \\
932774 \\
\end{array}$ & $\begin{array}{l}28183 / 0,5 / 1,3 \\
77426 / 2,6 / 8,3\end{array}$ \\
\hline Кожевниковский & Кожевниковское & 184200 & 16124 & $44 / 0,02$ / 0,27 \\
\hline Колпашевский & Колпашевское & 1511604 & 461452 & $17876 / 1,2 / 3,9$ \\
\hline Кривошеинский & Кривошеинское & 468597 & 133697 & $12983 / 2,8 / 9,7$ \\
\hline Молчановский & Молчановское & 429485 & 178428 & $12159 / 2,8 / 6,8$ \\
\hline Парабельский & $\begin{array}{l}\text { Парабельское } \\
\text { Кедровское }\end{array}$ & $\begin{array}{l}1652051 \\
1840914\end{array}$ & $\begin{array}{l}548035 \\
622441 \\
\end{array}$ & $\begin{array}{c}9073 / 0,6 / 1,7 \\
58563 / 3,2 / 9,4\end{array}$ \\
\hline Первомайский & $\begin{array}{l}\text { Первомайское } \\
\text { Улу-Юльское }\end{array}$ & $\begin{array}{l}703403 \\
862708 \\
\end{array}$ & $\begin{array}{l}263016 \\
392007 \\
\end{array}$ & $\begin{array}{c}59729 / 8,5 / 22,7 \\
7072 / 0,8 / 1,8 \\
\end{array}$ \\
\hline Тегульдетский & Тегульдетское & 1187185 & 298921 & $115499 / 9,7 / 38,6$ \\
\hline Томский & $\begin{array}{l}\text { Корниловское } \\
\text { Тимирязевское } \\
\text { Томское } \\
\end{array}$ & $\begin{array}{c}210442 \\
264733 \\
53611 \\
\end{array}$ & $\begin{array}{c}76363 \\
110405 \\
15222 \\
\end{array}$ & $\begin{array}{c}18124 / 8,6 / 23,7 \\
8393 / 3,2 / 7,6 \\
6276 / 11,7 / 41,2 \\
\end{array}$ \\
\hline Чаинский & Чаинское & 599121 & 193550 & 52034 / 8,7 / 26,9 \\
\hline Шегарский & Шегарское & 310545 & 50360 & $3679 / 1,2 / 7,3$ \\
\hline иТОГО & & 28674272 & 9656762 & 621079 / 2,2 / 6,4 \\
\hline
\end{tabular}


вер Томской области обилие пихты резко падает, и пихтарники практически не встречаются в средней тайге, где эта порода только участвует в сложении полидоминантной темнохвойной тайги как субэдификатор.

Опираясь на выявленные особенности распространения $P$. proximus, можно сделать вывод о том, что северный предел современного ареала инвайдера в Томской области совпадает с северной границей подзоны южной тайги и распространения пихтарников, приуроченной примерно к 58-й параллели [Gorozhankina, Konstantinov, 1978].

Ведущим фактором, способствующим вселению $P$. proximus в новые местообитания, является состояние пихтовых древостоев. Спелые (возрастом 81120 лет) и перестойные (более 121 года) насаждения составляют, по данным Государственного лесного реестра, 62,9 \% площади пихтовых лесов Томской области. Учитывая, что пихта сибирская уже в возрасте 70-80 лет массово поражается гнилевыми инфекциями [Falaleev, 1982], можно заключить, что более половины пихтовых лесов области представлены древостоями, сильно ослабленными различными грибными патогенами, что делает их неустойчивыми к нападению насекомых-вредителей.

Начальное формирование очагов и расселение $P$. proximus на территории области могло быть обусловлено жаркой засушливой погодой 2005-2006 гг., с одной стороны, неблагоприятной для пихты, и, с другой стороны, обеспечившей развитие второго поколения полиграфа в сезоне и усиление активности разлёта жуков. В дальнейшем расширении ареала, несомненно, важную роль сыграло жаркое сухое лето в 2012, 2014 и 2016 гг., спровоцировавшее также нарастание численности сибирского шелкопряда D. sibiricus и небывалое увеличение зоны очагов его массового размножения в Сибири, в том числе в северном направлении. В связи с появлением повреждённых шелкопрядом пихтовых древостоев следует ожидать дальнейшей экспансии уссурийского полиграфа.

Для прогнозирования динамики ареала наибольший интерес представляют крайние точки местонахождений полиграфа. В Томской области наиболее северные находки P. proximus известны из окр. п. Тайное в Верхнекетском р-не (Белоярское участковое лесничество Верхнекетского лесничества, 2013 г.) и из окр. г. Колпашево (урочище Городское Колпашевского участкового лесничества Колпашевского лесничества, 2017 г.). Пихта сибирская на этих участках произрастает на дерново-подзолистых остаточно карбонатных почвах со вторым гумусовым горизонтом с признаками глубокой глееватости, представляющих собой в правобережье Оби северные форпосты аналогичных почв, на которых пихта массово встречается в южной тайге [Afanas'eva, Vasilenko, 1977].

Севернее, в Парабельском и Каргасокском районах области, такие почвы с произрастающими на них темнохвойными лесами с заметным участием пихты встречаются только в левобережье Оби, в поймах рек Парабель, Васюган и его притоков. Здесь вероятны новые находки $P$. proximus, в том числе в связи с обнаружением в этих районах в 2016 г. очагов массового размножения сибирского шелкопряда, как фактора ослабления пихты и создания кормовой базы для продвижения инвайдера на север и запад области. В южных частях этих районов, в том числе на территории Васюганского и Кедровского лесничеств, его появление можно ожидать в ближайшее время.

\section{Благодарности}

Авторы благодарят Томский филиал ФБУ «Рослесозащита», Департаменты лесного хозяйства и охраны окружающей среды и природопользования Томской области за предоставленные сведения о распространении уссурийского полиграфа и содействие при проведении экспедиционных работ.

Исследования выполнены при финансовой поддержке РФФИ и Томской области в рамках научного проекта № 16-44-700782.

\section{Литература}

Afanas'eva T.V., Vasilenko T.I. 1977. The soils // Natural conditions of the central part of the West Siberian Plain. Moskva: Izdatel'stvo Moskovskogo universiteta. P.80-112. [In Russian].

Baranchikov Yu.N. 2012. Invasions of dendrophilous insects - a source of economic problems and a testing ground for ecological and evolutionary research // Ecologicheskie i ekonomicheskie posledstviya invazii dendrofil'nykh nasekomykh. Materialy Vserossiskoi konferentsii, 2012, Krasnoyarsk. Krasnoyarsk: Institut lesa SO RAN. P.6-11. [In Russian].

Baranchikov Yu., Akulov E., Astapenko S. 2010. Bark beetle Polygraphus proximus: a new invader on Abies species in Siberia and European Russia// McManus K.A., Gottschalk K.W. (Eds.): Proceedings. 21 ${ }^{\text {st }}$ U.S. Department of Agriculture Interagency research forum on invasive species, 2010, Annapolis, MD. Gen. Tech. Rep. NRS-P-75. Newtown Square, PA: U.S. Department of Agriculture, Forest Service, Northern Research Station. P.64-65.

Baranchikov Yu.N., Krivets S.A. 2010. On professionalism in determining insects: how overlooked the appearance of a new aggressive fir pest in Siberia // Ekologiya Yuzhnoy Sibiri i sopredel'nykh territoriy. Abakan: Khakasskiy gosudarstvennyy universitet im. N.F. Katanova. Is.14. Vol.1. P.50-52. [In Russian].

Baranchikov Yu.N., Pet'ko V.M., Astapenko S.A., Akulov E.N., Krivets S.A. 2011a. Four-eyed fir bark beetle a new aggressive pest of fir in Siberia // Lesnoy vestnik. Vestnik Moskovskogo gosudarstvennogo universiteta lesa. No.4(80). P.78-81. [In Russian].

Baranchikov Yu.N., Krivets S.A., Pet'ko V.M., Kerchev I.A., Mizeeva A.S., Anisimov V.A. 2011b. [In pursuit of four-eyed fir bark beetle Polygraphus proximus Blandf.] // Ekologiya Yuzhnoy Sibiri i sopredel'nykh territoriy. Abakan: Khakasskiy gosudarstvennyy universitet im. N.F.Katanova. Vol.15. No.1. P.52-54. [In Russian].

Chmyr A.F., Markova N.A., Sennov S.N. 2001. [Methodology of silvicultural research: Methodical manual]. SanktPeterburg: Leningragskaya lesokhozyaistvennaya akademiya. 96 p. [In Russian].

Demidko D.A. 2014. [Date of invasion of four-eyed fir bark beetle Polygraphus proximus Blandf. (Coleoptera: Curculionidae, Scolytinae) on the territory of Tomskaya Oblast'] // Izvestia Sankt-Peterburgskoi Lesotehniceskoi Akademii. Vol.207. P.225-234. [In Russian]. 
Dgebuadze Yu.Yu. 2014. [Invasions of alien species in Holarctic: some results and perspective of investigations] // Russkyi zhurnal biologicheskikh invazii. No.1. P.2-8. [In Russian].

Falaleev E.N. 1982. [The fir]. M.: Izdatel'stvo Lesnaya promyshlennost'. 86 p. [In Russian].

[Four-eyed fir bark beetle in the forests of Siberia (distribution, biology, ecology, detection and examination of damaged stands)]. Methodical manual]. 2015. / Krivets S.A., Kerchev I.A., Bisirova E.M., Pashenova N.V., Demidko D.A., Pet'ko V.M., Baranchikov Yu.N. Tomsk-Krasnoyarsk: Izdatel'skii Dom «UMIUM». 48 p. [In Russian].

Gorozhankina S.M., Konstantinov V.D., 1978. [Geography of taiga of Western Siberia]. Nobosibirsk: Nauka, Sibirskoe otdelenie. 190 p. [In Russian].

Kerchev I.A., Krivets S.A. 2012. [Outbreak foci of four-eyed fir bark beetle Polygraphus proximus in fir forests of Tomskaya Oblast'] // VIII Mezhdunarodnyi nauchnyi kongress "Interexpo GEO-Sibir'-2012". Sbornik materialov nauchno konferentsii «Ekonomicheskoe razvitie Sibiri i Dal'nego Vostoka. Ekonomika prirodopol'zovaniya, zemleustroystvo, lesoustroystvo, upravlenie nedvizhimost'yu», 2012, Novosibirsk. Novosibirsk: SGGA. Vol.4. P. 67-72. [In Russian].

Kononov A., Ustyantsev K., Blinov A., Fet V., Baranchikov Yu.N. 2016. Genetic diversity of aboriginal and invasive populations of four-eyed ûr bark beetle Polygraphus proximus Blandford (Coleoptera, Curculionidae, Scolytinae) // Agricultural and Forest Entomology. Vol.18. No.3. P.294-301.

Krivets S.A., Baranchikov Yu.N., Pashenova N.B., Bisirova E.M., Kerchev I.A., Pet'ko V.M., Pats E.N., Chernova N.A. 2013. [The role of the invasive dendrophage Polygraphus proximus Blandf. in the current processes of degradation of fir forests in Southern Siberia] // Bioraznoobrazie, problemy ekologii Gornogo Altaya i sopredel'nykh regionov: nastoyashchee, proshloe, budushchee: materialy III mezhdunarodnoy konferentsii, 2013, Gorno-Altaysk. GornoAltaysk: Gornoaltaiskii gosudarstvennyi universitet. P.262266. [In Russian].

Krivets S.A., Kerchev I. A., Kizeev Yu.M., Kozhurin M.A., Kozak R.G., Filimonov M.N., Chemodanov A.V., Chugin V.S. 2011. [Four-eyed fir bark beetle Polygraphus proximus Blandf. (Coleoptera, Scolytidae) in the fir forests of the Tomskaya Oblast'] // Bolesni i vrediteli v lesakh Rossii: XXI vek. Materialy Vserossiyskoy konferentsii i V ezhegodnykh chteniy pamyati O.A. Kataeva, 2011, Ekaterinburg. Krasnoyarsk: Institut lesa SO RAN. P.53-55. [In Russian].

Krivets S.A., Bisirova E.M., Kerchev I.A., Pats E.N., Chernova N.A. 2015a. Transformation of Taiga ecosystems in the Western Siberian invasion focus of four-eyed fir bark beetle Polygraphus proximus Blandford (Coleoptera: Curculionidae, Scolytinae) // Russian Journal of Biological Invasions. Vol.6. No.2. P.94-108.

Krivets S.A., Kerchev I.A., Bisirova E.M., Demidko D.A., Pet'ko V.M., Baranchikov Yu.N. 2015b. [Distribution of four-eyed fir bark beetle Polygraphus proximus Blandf. (Coleoptera, Curculionidae: Scolytinae) in Siberia] // Izvestia SanktPeterburgskoi Lesotekhniceskoi Akademii. Vol.211. P.3345. [In Russian].

Krivolutskaya G.O. 1958. [Bark beetles of Sakhalin Island]. ML.: Izdatel'stvo Akademii Nauk USSR. 196 p. [In Russian]. Kurentsov A.I. 1950. [Pest insects of coniferous species of Primorskii Krai]. Vladivostok. 256 p. [In Russian].

Nobuchi A. 1979. Studies on Scolytidae XVIII. Bark beetles of tribe Polygraphini in Japan (Coleoptera, Scolytidae) // Bulletin of the Forestry and Forest Products Research Institute. No.308. P.1-16.

Sochava V.B. 1980. [Geographical aspects of the Siberian taiga]. Nobosibirsk: Nauka. 256 p. [In Russian].

Stark V.N. 1952. [Bark beetles / Fauna of the USSR. Coleoptera]. Vol.XXXI. M.-L.: Izdatel'stvo Akademii Nauk USSR. 462 p. [In Russian].

Поступила в редакцию 25.9.2017 